\title{
Trans-Holocene Marine Mammal Exploitation on San Clemente Island, California: A Tragedy of the Commons Revisited
}

\author{
Judith F. Porcasi \\ Zooarchaeology Laboratory, Cotsen Institute of Archaeology, University of California, Los Angeles, California 90095-1510 \\ Terry L. Jones \\ Department of Social Sciences, California Polytechnic State University, San Luis Obispo, California 93407 \\ and \\ L. Mark Raab \\ Department of Anthropology, California State University, Northridge, California 91330

\begin{abstract}
Occupied from ca. 7040 B.C. to A.D. 1400, the Eel Point Site (CA-SCLI-43) on San Clemente Island, California represents one of the longest sequences of near-continuous marine resource exploitation on the west coast of North America. Faunal remains suggest transitions from heavy exploitation of fur seals and sea lions during the early Holocene, to increased hunting of cetaceans at mid-Holocene, to a focus on sea otters and fish during the late Holocene. These trends are consistent with patterns of overexploitation and economic intensification on the California and Oregon mainland, but they also suggest watercraft-based hunting earlier on the island than elsewhere. Fur seal and sea lion bones mainly represent females and juveniles, indicating that exploitation of island rookeries was guided more by self-interest than by principles of game conservation. Two intervals of temporary site abandonment, ca. 6150-3970 B.C. and A.D. 1020-1400, were both followed by periods of increased marine mammal exploitation and may reflect intervals during which marine mammal populations rebounded. Broadscale diachronic trends in the zooarchaeological remains do not correlate with flux in paleo-sea temperatures and are best interpreted as products of overhunting and increased use of watercraft over time.
\end{abstract}

With the increasing application of optimal foraging and/or economic intensification theories to models of hunter-gatherer subsistence (see Beaton 1991; Basgall 1987; Broughton 1994, among others), long-standing cultural ecological interpretations of forager prehistory are coming under renewed scrutiny. Based on a premise of relentless human adaptation, many traditional cultural ecological interpretations emphasize a limited relationship between humans and their environment. Environmental change, for ex- ample, is commonly envisioned as a strictly natural or climatic phenomenon routinely accommodated by simple adaptive adjustments and/or migrations by humans (see Moratto 1984). These models portray human/environmental relationships as largely unidirectional; culture is perceived as being influenced by the natural environment, but there are often no catastrophes or violence and little consideration of the possible impact of humans on their surroundings. In models in which the influence of hunter-gatherers on nat- 
ural ecosystems is acknowledged, effects are often interpreted in a strictly positive light, as human intervention into biological processes is perceived as increasing the productivity and vitality of habitats (Bean and Lawton 1976; Blackburn and Anderson 1993; Williams and Hunn 1982). Recent and growing recognition of violence in hunter-gatherer prehistory (see Edgerton 1992; Lambert 1993; Lambert and Walker 1991; Keeley 1996), suggests that other premises of cultural ecology may be equally suspect. Human impact on prehistoric fauna, particularly large animals, is one possibility that challenges cultural ecological models in which hunter-gatherer subsistence practices are portrayed in terms of relentless adaptive equilibrium.

The possibility that prehistoric humans impacted North American fauna is not a new idea. It was raised at least as early as 1916 when Gifford (1916:10) suggested that overexploitation was the most likely cause underlying stratigraphic variation in invertebrate remains in San Francisco Bay shell mounds. More than 60 years later, Botkin (1980) suggested that a decrease in mean shell size over time in a southern California coastal midden was probably a reflection of excessive harvesting. Overhunting has also been championed by Paul Martin since 1967 as the possible cause of megafauna extinctions. Most of these early models were conjectural in that they either lacked empirical support from the prehistoric faunal record or, in the case of Botkin, failed to place faunal data in a chronological context that allowed for alternative influences to be evaluated. More recently, however, in concert with the rise in application of optimal foraging concepts, human overhunting has been implicated as a likely influence in the population histories of North American elk (Kay 1990, 1994), deer (Broughton 1994), and bison (Geist
1996; Truett 1996), bolstered in some cases with well-dated archaeological findings.

Divergent interpretations of California and Oregon archaeofaunas recently prompted debate over possible overexploitation of northeastern Pacific marine mammal populations during the Holocene. In two papers Hildebrandt and Jones (Hildebrandt and Jones 1992; Jones and Hildebrandt 1995) suggested that hunting of fur seals and sea lions along California and Oregon shores approximated a prehistoric "tragedy of the commons" in which rookeries of terrestrialbreeding sea lions and fur seals were overexploited, necessitating pursuit of smaller, more elusive taxa (harbor seals and sea otters) that breed at sea and can only be caught through the use of sophisticated maritime weaponry and boats. In opposition, Lyman (1995) suggested that prehistoric hunting of marine mammals was more conservation-oriented, that some mainland rookeries persisted into historic times aided by selective culling of herds, and that the potential for rapid population recovery mitigated short-term decimation. Developed from the principles of optimal foraging (see Hawkes et al. 1982; O'Connell and Hawkes 1981, among others), which suggest that foragers should target resources with greatest net energy returns and only add lowerranked foods to the diet as the more energy-efficient resources become less available, the overexploitation model was also posed as a contrast to cultural ecological constructs from southern California that emphasize human adaptive response to paleo-sea temperature change (e.g., Arnold 1992a, 1992b; Colten 1993, 1995; Davenport et al. 1993; Glassow et al. 1988; see Raab and Larson 1997). This debate speaks directly to larger issues concerning the role of human predation in the evolution of North American ecosystems and divergent characterizations of prehistoric 
human hunters alternatively as resource managers (see Blackburn and Anderson 1993; Hunn and Williams 1982) or selfinterested contributors to faunal extirpation, extinction, and environmental modification.

The Jones and Hildebrandt (1995) argument for a tragedy of the commons in the northeastern Pacific was based on a large suite of zooarchaeological data from California and Oregon unintentionally weighted toward the late Holocene and spatially toward northern and central California. While faunal collections representing human predation on marine mammals extending back to the early Holocene and ultimately to the era of initial human colonization are necessary to fully evaluate the overexploitation model, such data simply were not available from the northeastern Pacific until more recently. As Lyman (1995) further pointed out, the overexploitation model also suffered from a paucity of age/sex information and lack of clear evidence for species changes over time. A detailed record of prehistoric marine mammal hunting extending back nearly 9000 years is now available from the Eel Point Site on San Clemente Island off the coast of southern California (Porcasi 1995; Raab and Yatsko 1992; Salls 1989, $1990,1991,1992)$. The faunal data from this site represent one of the longest sequences of near-continuous marine resource exploitation on the west coast of North America. Patterns in the marine mammal remains exclusively support neither cultural ecological (environmental/adaptive) nor human overexploitation models, but instead suggest influences from both contextual/paleoenvironmental flux and human overexploitation. In many cases, however, patterns of species replacement and age/ sex selection are clearly inconsistent with resource conservation.

\section{ALTERNATIVE PERSPECTIVES ON MARINE MAMMAL EXPLOITATION}

Based on the archaeofaunal record from northern California and Oregon, Hildebrandt and Jones (1992) contended that pinniped rookeries were heavily exploited during the early and middle Holocene with no evident consideration for resource conservation. They suggested that decreased availability of the highly ranked pinnipeds prompted advent of seaworthy watercraft and more sophisticated hunting equipment to pursue pinnipeds and lower ranked marine mammals (sea otters) in offshore contexts. The increased cost and reduced availability of prey in offshore situations, however, accounted for the survival (albeit in lower numbers) of the higher-ranked taxa. Lyman (1995) argued that not all of the data brought by Hildebrandt and Jones supported the position that prehistoric exploitation resulted in destruction of mainland rookeries and dietary shifts to lower-ranked species. He also rejected the suggestion that improved watercraft and hunting technology served to perpetuate more costly, labor-intensive predation on terrestrially breeding species in offshore settings when mainland rookeries were depleted.

Hildebrandt and Jones made specific rank assignments for the marine mammals of the northeastern Pacific based largely on size, behavior, and particularly reproductive biology. Taxa that must breed and give birth onshore and occupy large onshore breeding colonies (terrestrial breeders) were ranked highest. These species include Guadalupe fur seals (Arctocephalus townsendi), northern fur seals (Callorhinus ursinus), elephant seals (Mirounga angustirostris), California sea lions (Zalophus californianus), and Steller sea lions (Eumetopias jubatus). Smaller taxa that breed effectively at sea and congregate in smaller numbers (the "resident breed- 
ers")- harbor seals (Phoca vitulina) and sea otters (Enhydra lutris) -were considered lower-ranked resources. Archaeofaunal remains from most of the Oregon and northern and central California mainland sites showed consistent decreases in terrestrial breeders through time coeval with increases in harbor seals and/or sea otters. Quantified data from southern California were largely limited to findings from the breeding colony on San Miguel Island, and were more equivocal, as terrestrial breeders initially declined, but later showed some signs of a population rebound. Jones and Hildebrandt (1995) suggested that prolonged droughts during the early centuries of the present millennium (see Graumlich 1993; Stine 1994) may have forced humans to abandon some or all of the more poorly watered Channel Islands, giving marine mammal populations opportunity for both shortand long-term recovery.

Traditional cultural ecological models of California coastal prehistory ascribe a stronger measure of causality to paleoclimatic variability. Rather than the gradual, unidirectional changes in species proposed by Hildebrandt and Jones as reflections of optimal foraging, human population growth, and resource overexploitation, other researchers propose multidirectional parallels between sea temperature and marine resource acquisition. Glassow et al. (1988), for example, attributed an apparent mid-Holocene increase in marine mammal hunting in the Santa Barbara Channel to a decline in sea temperature and increased vitality in the marine ecosystem. Others (Arnold 1992a, 1992b, 1995, 1997; Arnold et al. 1997; Colten 1993, 1995) suggest that warm seas ca. A.D. 1250 were associated with dramatic changes in settlement and subsistence that included the development of sophisticated watercraft and emergence of complex systems of sociopolitical organization. Raab et al. (1995) correctly pointed out that water temperatures may have influenced the mix of species available to prehistoric hunters, but did not necessarily dictate the intensity of exploitation. Porcasi (1995) identified a mid-Holocene peak in marine mammal exploitation during fluctuating intervals of relatively warm water temperatures recently documented by Kennett (1998). These alternative perspectives clearly have different implications for the marine mammal zooarchaeological assemblages. Overexploitation should be reflected by a gradual replacement of highly ranked by lowerranked taxa, while the paleo-sea temperature model implies sudden changes in species and hunting intensity ca. mid-Holocene and A.D. 1250. The fauna from Eel Point were evaluated with these alternatives in mind.

\section{THE EEL POINT SITE (CA-SCLI-43), SAN CLEMENTE ISLAND}

San Clemente, the southernmost and fourth largest $\left(148 \mathrm{~km}^{2}\right)$ of the eight Channel Islands of southern California, is located $61 \mathrm{~km}$ from the mainland. Its nearest island neighbors are Santa Catalina and San Nicolas, approximately 39 and 97 $\mathrm{km}$ distant, respectively (Fig. 1). San Clemente Island has been a military reservation since 1934 and has not been accessible to the public since then. There are no burrowing animals on the island, and site preservation and stratigraphy are exceptional. Unlike the California mainland where postdepositional impacts create homogeneous middens with minimal stratigraphic integrity, San Clemente Island deposits show minimal signs of secondary disturbance. Even where some strata appear to have been exposed on the surface for extended periods, there is little or no evidence of breakage or crushing of faunal material. Bones and shells are commonly recovered in remarkably complete condition even from the deepest site lev- 


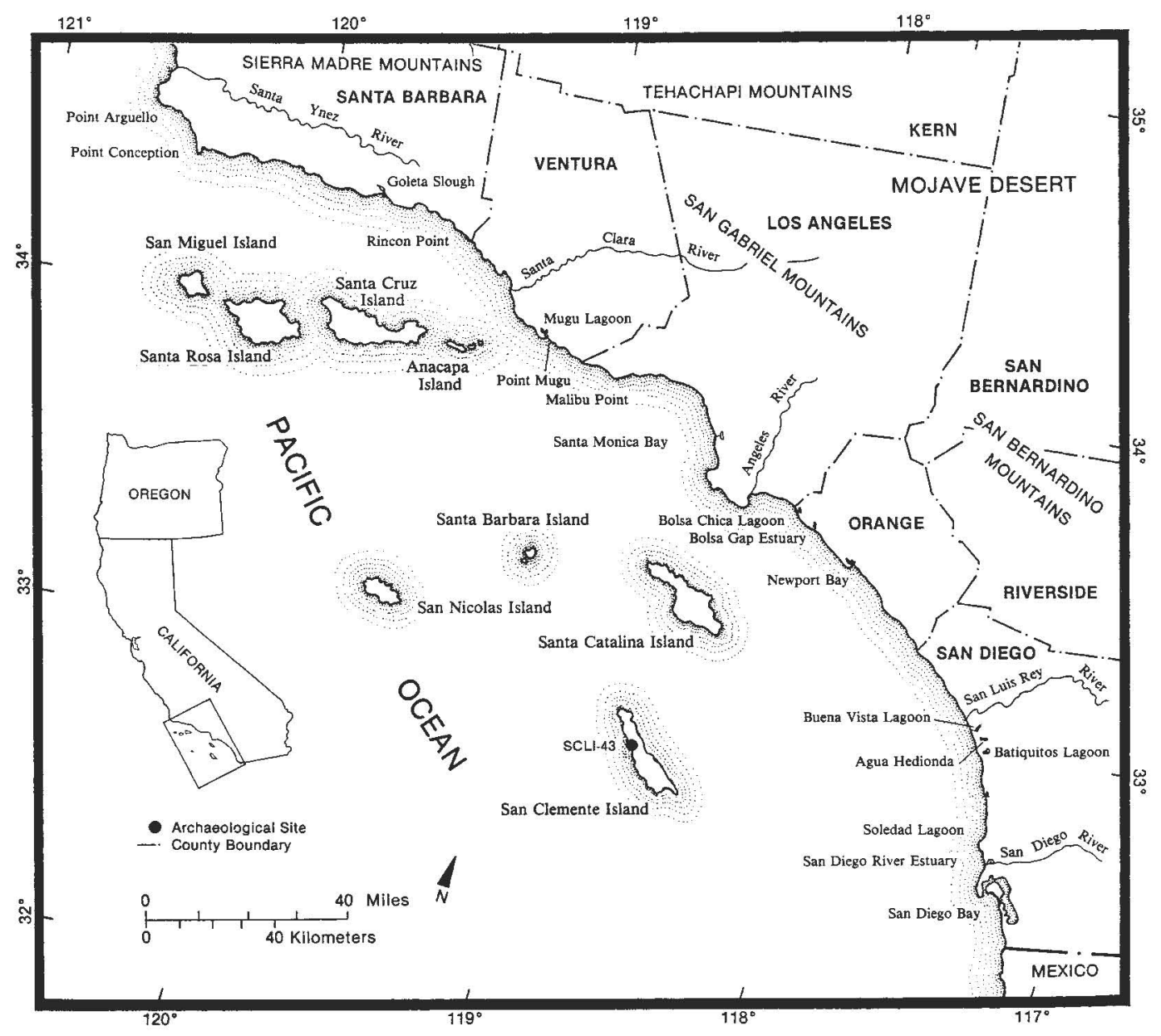

FIG. 1. San Clemente Island and the southern California Bight.

els. Perishable artifacts including basketry fragments made of Juncus sp. and sea grass are recovered from open, non-rockshelter contexts. A particularly well-preserved pouch of sea grass recovered from one such open site (CA-SCLI-1215) yielded a radiocarbon date of ca. A.D. 550 (Salls 1989). The Eel Point Site even produced prehistoric coprolites from strata dating nearly 2000 B.C. Stratigraphic integrity is also indicated at San Clemente Island by consistent superposition of radiocarbon dates.

In 1994 and 1996, California State University Northridge (CSUN) undertook ex- cavations at the Eel Point Site (CA-SCLI43), located on a rocky headland on the western shore of the island (Fig. 2). The investigation was completed under the direction of L. Mark Raab through a joint research agreement with the U. S. Navy Natural Resources Office. The site is an expansive mound of stabilized dunes containing and capping intact, highly stratified midden deposits up to $3 \mathrm{~m}$ deep. Previous test excavations (McKusick and Warren 1959; Axford 1978, 1984; Aycock 1983; Armstrong 1985; Meighan 1984, 1986; Raab and Yatsko 1992; Salls 1988, 1990, 1991, 1992) suggested the site was occu- 


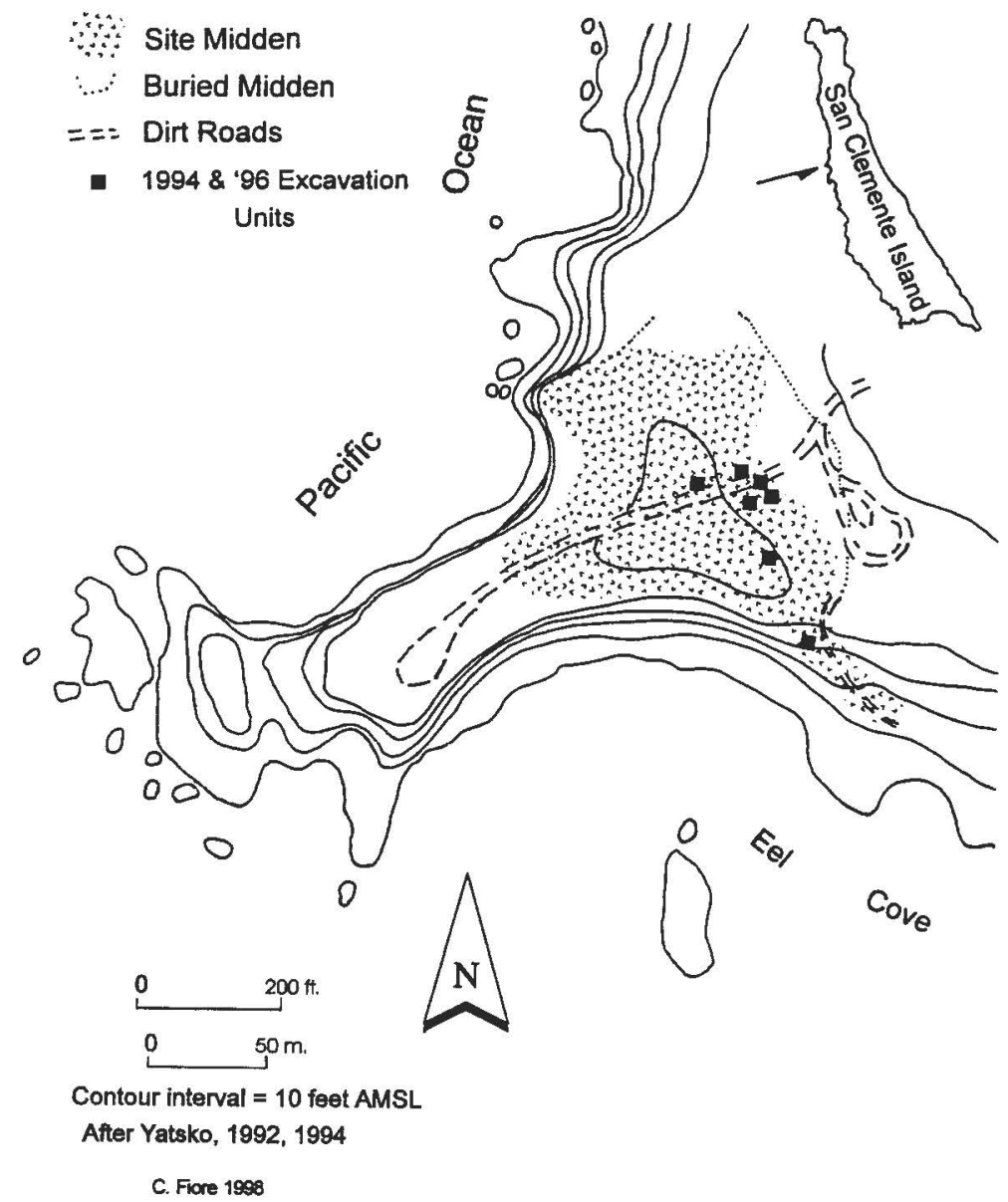

FIG. 2. The Eel Point Site, CA-SCLI-43.

pied between 7000 B.C. and A.D. 500. The only native terrestrial mammals are the tiny island fox (Urocyon littoralis) and a small non-burrowing deer mouse (Peromyscus maniculatus). The record of faunal exploitation, therefore, reflects nearly exclusive reliance on marine taxa.

A detailed chronology of stratigraphy and site use, developed from the 1994 and 1996 excavations, provides a temporal framework for the faunal data. A total of 13 test units (excavation volume $=33.08$ $\mathrm{m}^{3}$ ) revealed 120 discrete strata, from which 42 radiocarbon dates on shell and charcoal (corrected for isotope fractionation and the reservoir effect, and cali- brated with the Stuiver and Reimer [1993] program) were obtained. These dates establish a solid chrono-stratigraphic sequence of 28 strata across the site that testifies to occupation from ca. 7040 B.C. to A.D. 1400 (Table 1). The distribution of dates shows a significant hiatus of ca. 1800 years between 6150 and 3970 B.C. and a briefer hiatus between A.D. 1020 and 1400 in an otherwise long, regular occupation.

\section{HISTORIC/CONTEMPORARY MARINE MAMMAL POPULATIONS}

San Clemente Island currently serves as a rookery for California sea lions and ele- 
TABLE 1

Corrected and Calibrated Radiocarbon Dates from CA-SCLI-43

\begin{tabular}{|c|c|c|c|c|c|c|c|}
\hline Lab no. & Unit & Stratum & Material & $\begin{array}{l}{ }^{14} \mathrm{C} \\
\text { Correction }\end{array}$ & ${ }^{13} \mathrm{C} /{ }^{12} \mathrm{C}$ & $\begin{array}{l}\text { Calendric } \\
\text { date }\end{array}$ & $\begin{array}{l}1 \text { Sigma } \\
\text { probability }\end{array}$ \\
\hline BETA-76132 & $\mathrm{A}$ & $4 \mathrm{~A}$ & Charcoal & $2000 \pm 90$ & $2020 \pm 90$ & 2 B.C. & 110 B.C.-A.D. 80 \\
\hline BETA-76133 & $\mathrm{A}$ & $5 \mathrm{~A}$ & Charcoal & $2540 \pm 60$ & $2540 \pm 60$ & 770 B.C. & $800-760$ B.C. \\
\hline BETA-76130 & $\mathrm{A}$ & 6 & Shell & $7500 \pm 70$ & $7930 \pm 70$ & 6160 B.C. & 6230-6060 B.C. \\
\hline BETA-76134 & $\mathrm{B}$ & $5 \mathrm{~A}$ & Shell & $2360 \pm 70$ & $2800 \pm 70$ & 320 B.C. & $370-180$ B.C. \\
\hline BETA-76135 & B & 6 & Shell & $3560 \pm 70$ & $4010 \pm 70$ & 1740 B.C. & $1870-1660$ B.C. \\
\hline BETA-76136 & B & $6 \mathrm{~A}$ & Sea urchin & $3990 \pm 80$ & $4370 \pm 90$ & 2250 B.C. & $2400-2120$ B.C. \\
\hline BETA-76137 & B & $6 \mathrm{~B}$ & Charcoal & $4000 \pm 100$ & $4000 \pm 100$ & 2490 B.C. & $2620-2450$ B.C. \\
\hline BETA-76138 & B & $7 \mathrm{~B}$ & Charcoal & $4090 \pm 90$ & $4090 \pm 90$ & 2610 B.C. & $2870-2800$ B.C. \\
\hline BETA-76139 & B & 9 (Feat. 2) & Shell & $5260 \pm 80$ & $5700 \pm 80$ & 3920 B.C. & $3980-3780$ B.C. \\
\hline BETA-76140 & B & 10 & Charcoal & $4860 \pm 190$ & $4860 \pm 190$ & 3650 B.C. & 3910-3880 B.C. \\
\hline BETA-75092 & B & 11 & Shell & $5060 \pm 50$ & $5510 \pm 50$ & 3680 B.C. & $3750-3630$ B.C. \\
\hline BETA-75555 & B & 11 & Charcoal & $5470 \pm 160$ & $5500 \pm 160$ & 4350 B.C. & $4470-4220$ B.C. \\
\hline BETA-76141 & $\mathrm{C}$ & $2 \mathrm{~B}$ & Charcoal & $1380 \pm 60$ & $1390 \pm 60$ & A.D. 660 & A.D. $630-680$ \\
\hline BETA-76142 & $\mathrm{C}$ & $3 \mathrm{C}$ & Charcoal & $1620 \pm 100$ & $1640 \pm 100$ & A.D. 420 & A.D. $260-280$ \\
\hline BETA-76143 & $\mathrm{C}$ & 6 & Shell & $5330 \pm 80$ & $5780 \pm 90$ & 3970 B.C. & 4080-3910 B.C. \\
\hline BETA-75093 & $\mathrm{C}$ & Basal & Shell & $7490 \pm 70$ & $7910 \pm 70$ & 6150 B.C. & $6210-6040$ B.C. \\
\hline BETA-76021 & C & Basal & Charcoal & $8120 \pm 310$ & $8110 \pm 300$ & 7040 B.C. & $7480-7450$ B.C. \\
\hline BETA-76144 & $2 \mathrm{~N} / 35 \mathrm{E}$ & 3 & Charcoal & $1020 \pm 50$ & $1020 \pm 50$ & A.D. 1020 & A.D. $990-1030$ \\
\hline BETA-76145 & $2 \mathrm{~N} / 35 \mathrm{E}$ & 4 & Charcoal & $1890 \pm 50$ & $1900 \pm 50$ & A.D. 120 & A.D. $70-150$ \\
\hline BETA-76146 & $2 \mathrm{~N} / 35 \mathrm{E}$ & 5 & Charcoal & $1970 \pm 60$ & $2010 \pm 60$ & A.D. 5 & 50 B.C.-A.D. 70 \\
\hline BETA-76147 & $2 \mathrm{~N} / 35 \mathrm{E}$ & 6 & Charcoal & $1990 \pm 90$ & $2020 \pm 90$ & 2 B.C. & 110 B.C.-A.D. 80 \\
\hline BETA-76148 & $2 \mathrm{~N} / 35 \mathrm{E}$ & 7 & Charcoal & $2490 \pm 60$ & $2510 \pm 60$ & $\begin{array}{l}760 \text { B.C. } \\
620 \text { B.C. } \\
600 \text { B.C. }\end{array}$ & $790-520$ B.C. \\
\hline BETA-76149 & $2 \mathrm{~N} / 35 \mathrm{E}$ & 8 & Charcoal & $3050 \pm 90$ & $3030 \pm 90$ & 1270 B.C. & $1400-1120$ B.C. \\
\hline BETA-76150 & $2 \mathrm{~N} / 35 \mathrm{E}$ & 9 & Charcoal & $3240 \pm 80$ & $3250 \pm 80$ & 1520 B.C. & $1610-1420$ B.C. \\
\hline BETA-76151 & $2 \mathrm{~N} / 35 \mathrm{E}$ & 10 & Charcoal & $3320 \pm 110$ & $3320 \pm 110$ & $\begin{array}{l}1610 \text { B.C. } \\
1560 \text { B.C. } \\
1540 \text { B.C. }\end{array}$ & $1740-1710$ B.C. \\
\hline BETA-76153 & $2 \mathrm{~N} / 35 \mathrm{E}$ & 11 & Charcoal & $2890 \pm 50$ & $2910 \pm 50$ & 1110 B.C. & $1160-1140$ B.C. \\
\hline BETA-76152 & $2 \mathrm{~N} / 35 \mathrm{E}$ & 11 & Shell & $7720 \pm 130$ & $8140 \pm 130$ & 6380 B.C. & 6490-6220 B.C. \\
\hline BETA-77956 & $24.5 \mathrm{~S} / 77 \mathrm{E}^{a}$ & 3 & Charcoal & $580 \pm 60$ & $570 \pm 60$ & A.D. 1400 & A.D. $1380-1430$ \\
\hline BETA-77957 & $24.5 \mathrm{~S} / 77 \mathrm{E}^{a}$ & 8 & Charcoal & $1770 \pm 150$ & $1800 \pm 150$ & A.D. 240 & A.D. $70-420$ \\
\hline BETA-100564 & $27 \mathrm{~N} / 21 \mathrm{E}$ & 7 & Shell & $5700 \pm 60$ & $6140 \pm 60$ & 4350 B.C. & $4445-4320$ B.C. \\
\hline BETA-100565 & $27 \mathrm{~N} / 21 \mathrm{E}$ & 9 & Shell & $5200 \pm 60$ & $5660 \pm 60$ & 3880 B.C. & 3940-3770 B.C. \\
\hline BETA-100566 & $\mathrm{D}, \mathrm{E}, \mathrm{F}, \mathrm{G}^{b}$ & & Shell & $4110 \pm 60$ & $4560 \pm 60$ & 2480 B.C. & 2578-2430 B.C. \\
\hline BETA-100567 & $\mathrm{F}$ & 6 & Shell & $7530 \pm 80$ & $7960 \pm 80$ & 6180 B.C. & $6300-6110$ B.C. \\
\hline BETA-95897 & $28,29 \mathrm{~N} / 16 \mathrm{E}$ & 6 & Shell & $7790 \pm 60$ & $8210 \pm 60$ & 6440 B.C. & $6490-6380$ B.C. \\
\hline BETA-95898 & $28,29 \mathrm{~N} / 16 \mathrm{E}$ & $120 \mathrm{~A}$ & Charcoal & $7150 \pm 210$ & $7160 \pm 210$ & 5440 B.C. & $5610-5250$ B.C. \\
\hline BETA-95899 & $28,29 \mathrm{~N} / 16 \mathrm{E}$ & $120 \mathrm{~A}$ & Shell & $7670 \pm 90$ & $8110 \pm 90$ & 6360 B.C. & $6430-6230$ B.C. \\
\hline BETA-95900 & $28 / 29 \mathrm{~N} / 16 \mathrm{E}$ & $4 \mathrm{~B}$ & Shell & $5140 \pm 80$ & $5590 \pm 80$ & 3770 B.C. & 3900-3670 В.С. \\
\hline BETA-112518 & $28,29 \mathrm{~N} / 16 \mathrm{E}$ & 2 & Shell & $2060 \pm 60$ & $2080 \pm 60$ & A.D. 570 & A.D. $480-650$ \\
\hline
\end{tabular}

Note. Corrected and calibrated with the Stuiver and Reimer (1993) program. All shell dates corrected with a Delta R value of $225 \pm 35$ years (Stuiver and Braziunas 1993:138; 155-156; see also Taylor 1987:129).

${ }^{a}$ These two dates represent eight strata bracketed between A.D. 240 and 1403.

${ }^{b}$ Represents a profile across a basal house floor contiguous through four units.

phant seals. Females and young of both species share beaches on the west coast of the island. San Nicolas and San Miguel Islands to the north of San Clemente Island, however, serve as the primary elephant seal breeding sites on the Channel Islands. Harbor seals breed around San
Clemente, but these animals congregate in smaller groups and spend less time on land with their young. Archaeological and historical records testify to occasional landings of northern fur seals and Steller sea lions on San Clemente, but there is no evidence that these species ever bred 
there. It is likely that the Guadalupe fur seal bred on San Clemente before it was hunted to near extinction in historic times, although this animal currently breeds only on Guadalupe Island off the coast of Baja California, Mexico. Sea otters are seen in the kelp forests off San Clemente Island, but most of the modern population of otters-descendants of survivors of 19th Century extirpation (Bartholomew 1967; Scammon 1874) - is confined to waters north of Point Conception.

Two species of porpoise occur in offshore waters: Dall's porpoise (Phocoenoides dalli) and the harbor porpoise (Phocoena phocoena), with the latter being much more common. Eight dolphins are also present today: two species of common dolphin (Delphinus capensis and $D$. delphis), Risso's dolphin (Grampus griseus), Pacific white-sided dolphin (Lagenorhynchus obliquidens), northern right whale dolphin (Lissodelphis borealis), Pacific spotted dolphin (Stenella attenuata), striped or blue and white dolphin ( $S$. coeruleoalba), and the bottle-nosed dolphin (Tursiops truncatus). Many species of large cetaceans also approach the island during seasonal migrations.

\section{THE MARINE MAMMAL ZOOARCHAEOLOGICAL COLLECTION}

The 1994 and 1996 excavations produced a total number of identified specimens (NISP) of 10,118 marine mammal bones (some $14 \mathrm{~kg}$ ), of which 2403 (23.7\%) were identified to order, family, genus or species levels using reference collections at the Natural History Museum of Los Angeles County, the University of California at Los Angeles Zooarchaeology Laboratory, and the Santa Barbara Museum of Natural History. The collections from these facilities include multiple examples of male, female, and juvenile individuals of all marine mammal taxa found prehis- torically in the vicinity of San Clemente Island. Of the 2403 identified bones, 922 specimens (38.4\%) were delphinidae (nearly all dolphin), 791 (32.9\%) were pinnipeds, 501 (20.8\%) were sea otters, and $189(7.9 \%)$ were unidentifed large cetaceans. Another 7715 specimens $(76 \%$ of the total collection) were unidentified mammal, but because only $1 \%$ of the entire identified archaeofauna represented terrestrial mammals, all unidentified mammal bone was considered to be marine mammal.

Age/sex determinations were made for all elements complete enough for evaluation. Two age classes were recognized: juvenile (including fetal, neonate, immature, and subadult) and adult. Juveniles were recognized by unossified or incompletely fused epiphyses and undeveloped muscle attachments of limb bones, phalanges, metapodials, vertebrae, and scapulae; unfused sutures of the acetabulum and cranium; and/or extremely small size. Adults were marked by fused epiphyses and sutures, well-developed muscle attachments, and size. Determinations of sex were based on the strong sexual dimorphism in size in the larger pinnipeds. Among sea lions, fur seals, and elephant seals, adult males are two to four times as large as adult females (Ingles 1947:397; Jameson and Peeters 1988:180; Lyman 1991:344-345; Odell 1981:67-97; Ono 1991: 109-111; Trillmich 1991:45-46). This differential is readily reflected in the size and robusticity of skeletal elements and can be recognized in zooarchaeological analysis. This distinction is exemplified by statistically significant differences in measurements of length of femora and humeri from specimens of known sex and age of California sea lion (Table 2). Sexual differentiation is unquantified for other taxa, but the degree of dimorphism is comparable among living animals, so sex-diagnostic size variation can be recognized in archaeological skeletal elements for the 
TABLE 2

Length of Male versus Female Femora and Humeri for California Sea Lion Specimens from Museum Collections

\begin{tabular}{lcccc}
\hline & Male humerus & Female humerus & Male femur & Female femur \\
\hline$N$ & 17 & 9 & 10 & 5 \\
Mean (mm) & 218.4 & 153.6 & 125.9 & 90.6 \\
Range (mm) & $193.0-230.0$ & $144.6-170.4$ & $117.0-134.0$ & $87.3-95.7$ \\
Standard deviation & 10.06 & 8.23 & 5.74 & \multicolumn{2}{c}{$t=12.13$} \\
Variance & \multicolumn{2}{c}{$\begin{array}{c}t=15.48 \\
\text { Significance }\end{array}$} & \multicolumn{2}{c}{$p=<.001$} \\
\hline
\end{tabular}

large pinnipeds. Sexual dimorphism is less pronounced among harbor seals and sea otters.

Faunal data were manipulated as follows: First, overall NISP $/ \mathrm{m}^{3}$ values were calculated for each of the 28 dated strata (Table 3) and for each identified species or animal class represented in each dated stratum (Table 4). This provided a relatively fine-grained chronological sequence, but one in which $\mathrm{NISP} / \mathrm{m}^{3}$ values for some individual strata were uncomfortably low. It also excluded bones from intervening, undated strata. To mitigate these problems, two "lumping" procedures were employed. The first was an extrapolation that allowed all of the marine mammal bone (identified or unidentified) from all strata (dated and undated) to be included. To accomplish this, unidentified marine mammal bone was incorporated into the four major animal categories (pinnipeds, delphinidae, otters, and larger cetaceans) in proportion to the percentage of identified specimens in each stratum. The second procedure was intended to provide more robust numbers by using a more coarse-grained temporal structure. To accomplish this, the Holocene was divided into five periods: Early (8000-5000 B.C.), undated Early/Middle (UE/M), Middle (5000-1500 B.C.), undated Middle/Late (UM/L), and Late Holocene (1500 B.C.-A.D. 1400). The undated periods derive from strata for which no radiocarbon evidence is available, but their stratigraphic position between dated layers allows for relative temporal placement. The exceptional stratigraphy at Eel Point allows for this assumption to be made with confidence. The lumping procedures yielded a coarse-grained yet complete summary of marine mammal utilization through time at Eel Point (Table 5 and Fig. 3). The finer-grained temporal structure, in which the total collection is presented on a 1000-year incremental time scale, was also retained (Fig. 4). Relative trends that were the same or nearly similar in both manipulations were considered most meaningful and worthy of further discussion.

\section{Patterns through Time}

When the faunal material is ordered in this manner, significant diachronic trends are apparent. First, it is clear that marine mammals were exploited throughout the occupation. Throughout the sequence, the main prey were California sea lions, Guadalupe fur seals, sea otters, and several species of small cetaceans (dolphins) (Tables 6 and 7). Dolphins were not considered in the original Hildebrandt and Jones overexploitation model and are discussed separately below. Insignificant quantities of harbor seal and elephant seal bones were also recovered. In terms of both percentage and bone frequency $/ \mathrm{m}^{3}$ (Figs. 3 and 4), pinniped remains dominate the earliest component to the near 
TABLE 3

Marine Mammal Bone Frequency per Cubic Meter from 28 Dated Strata, CA-SCLI-43

\begin{tabular}{|c|c|c|c|c|}
\hline Unit (stratum) & Date & NISP & $\begin{array}{c}\text { Stratum } \\
\text { volume }\left(\mathrm{m}^{3}\right)\end{array}$ & $\mathrm{NISP} / \mathrm{m}^{3}$ \\
\hline $24.5 \mathrm{~S} / 77 \mathrm{E}(3)$ & A.D. 1400 & 102 & 0.145 & 703.5 \\
\hline 2N/35 E (3) & A.D. 1020 & 41 & 0.320 & 128.0 \\
\hline $\mathrm{C}(2 \mathrm{~B})$ & A.D. 660 & 36 & 0.235 & 153.2 \\
\hline $28,29 \mathrm{~N} / 16 \mathrm{E}$ (2) & A.D. 570 & 88 & 0.200 & 440.0 \\
\hline$C(3 C)$ & A.D. 420 & 35 & 0.157 & 222.9 \\
\hline $24.5 \mathrm{~S} / 77 \mathrm{E}(8)$ & A.D. 240 & 19 & 0.225 & 84.4 \\
\hline $2 \mathrm{~N} / 35 \mathrm{E}$ (4) & A.D. 120 & 120 & 0.945 & 126.9 \\
\hline 2N/35E (5) & A.D. 5 & 73 & 0.155 & 470.9 \\
\hline $2 \mathrm{~N} / 35 \mathrm{E}(6)$ and $\mathrm{A}(4 \mathrm{~A})^{a}$ & 2 B.C. & 57 & 0.150 & 380.0 \\
\hline $\mathrm{B}(5 \mathrm{~A})$ & 320 B.C. & 1 & 0.028 & 36.4 \\
\hline $2 \mathrm{~N} / 35 \mathrm{E}(7)$ & 620 B.C. & 96 & 2.100 & 45.7 \\
\hline $\mathrm{A}(5 \mathrm{~A})$ & 770 B.C. & 154 & 0.480 & 320.8 \\
\hline $2 \mathrm{~N} / 35 \mathrm{E}(8)$ & 1270 B.C. & 27 & 0.415 & 65.1 \\
\hline 2N/35E (9) & 1520 B.C. & 7 & 1.570 & 4.5 \\
\hline 2N/35E (10) & 1560 B.C. & 77 & 0.200 & 385.0 \\
\hline $\mathrm{B}(6)$ & 1740 B.C. & 412 & 0.400 & 1030.0 \\
\hline $\mathrm{B}(6 \mathrm{~A})$ & 2250 B.C. & 38 & 0.085 & 447.1 \\
\hline D-G Profile ${ }^{b}$ & 2480 B.C. & 159 & 0.175 & 908.6 \\
\hline$B(6 B)$ & 2490 B.C. & 78 & 0.330 & 236.4 \\
\hline $\mathrm{B}(7 \mathrm{~B})$ & 2610 B.C. & 6 & 0.100 & 60.0 \\
\hline $28,29 \mathrm{~N} / 16 \mathrm{E}(4 \mathrm{~A})^{c}$ & 3640 B.C. & 20 & 0.200 & 100.0 \\
\hline B (10) & 3650 B.C. & 1 & 1.205 & 0.8 \\
\hline \multicolumn{5}{|l|}{$28,29 \mathrm{~N} / 16 \mathrm{E}(4 \mathrm{~B}), 26 \mathrm{~N} / 20,21 \mathrm{E}$} \\
\hline (8) and $31 \mathrm{~N} / 11,12 \mathrm{E}(8)^{\mathrm{a}}$ & 3770 B.C. & 88 & 0.200 & 440.0 \\
\hline C (6) & 3970 B.C. & 96 & 0.500 & 192.0 \\
\hline A (6) & 6160 B.C. & 6 & 0.173 & 34.8 \\
\hline 2N/35E (11) & 6380 B.C. & 29 & 0.620 & 46.8 \\
\hline 28, 29N/16E (6) & 6440 B.C. & 180 & 0.200 & 900.0 \\
\hline$C(9 C)$ & 7040 B.C. & 2 & 0.070 & 28.6 \\
\hline Total & & 2048 & 11.613 & \\
\hline
\end{tabular}

a Average values from multiple contemporaneous or contiguous strata.

${ }^{b}$ Represents a profile across a basal house floor contiguous through four units.

'Interface with 28, 29N/16E (4B).

exclusion of other taxa and are prominent for a portion of the middle Holocene, but decline thereafter, showing only a slight resurgence at the end of the occupational sequence ca A.D. 1400. Following the gap in early Holocene occupation (Fig. 4) (from 6150 to 3970 B.C), there is an overall increase in marine mammal exploitation, with a major rise in small cetaceans (Tables 5 and 6 , Figs. 3 and 4). Sea otter bones are nearly absent from the earliest component and become more numerous over time. On the coarse-grained temporal scale they show an incremental increase throughout the Holocene (Table 5, Fig. 3), while the more fine-grained scale shows more irregular increase with intervening pulses of decline. One middle Holocene peak in otter bone is coincident with an important increase in pinnipeds (Fig. 4). Both data manipulations show otter bones representing a major proportion of the assemblage during the late Holocene.

While pinniped remains made up most of the early Holocene collection, bones which could be positively identified as the 
TABLE 4

Marine Mammal and Fish Bone Frequency per Cubic Meter from 28 Dated Strata, CA-SCLI-43

\begin{tabular}{|c|c|c|c|c|c|c|c|c|c|c|c|c|}
\hline \multirow[b]{2}{*}{ Unit (stratum) } & \multirow[b]{2}{*}{ Date } & \multirow{2}{*}{$\begin{array}{l}\text { Phoca } \\
\text { vitulina }\end{array}$} & \multirow{2}{*}{$\begin{array}{l}\text { Arctocephalus } \\
\text { townsendi }\end{array}$} & \multirow{2}{*}{$\begin{array}{c}\text { Zalophus } \\
\text { californianus }\end{array}$} & \multirow{2}{*}{$\begin{array}{c}\text { Mirounga } \\
\text { angustirostris }\end{array}$} & \multirow{2}{*}{$\begin{array}{l}\text { Unidentified } \\
\text { pinniped }\end{array}$} & \multirow{2}{*}{$\begin{array}{c}\text { Total } \\
\text { pinniped }\end{array}$} & \multirow{2}{*}{$\begin{array}{l}\text { Enhydra } \\
\text { lutris }\end{array}$} & \multicolumn{2}{|c|}{ Unidentified } & \multirow{2}{*}{$\begin{array}{c}\text { Total } \\
\mathrm{NISP} / \mathrm{m}^{3}\end{array}$} & \multirow[b]{2}{*}{ Fish $^{a}$} \\
\hline & & & & & & & & & Cetaceans & Mammal & & \\
\hline 24.5S/77E (3) & A.D. 1400 & 0.0 & 0.0 & 6.9 & 0.0 & 41.4 & 48.3 & 117.2 & 0.0 & 537.9 & 703.5 & 5508.0 \\
\hline 2N/35E (3) & A.D. 1020 & 3.1 & 0.0 & 0.0 & 0.0 & 9.4 & 12.5 & 18.8 & 6.3 & 90.6 & 128.0 & 1021.5 \\
\hline $\mathrm{C}(2 \mathrm{~B})$ & A.D. 660 & 0.0 & 0.0 & 0.0 & 0.0 & 4.3 & 4.3 & 4.3 & 0.0 & 144.7 & 153.2 & 316.5 \\
\hline $28,29 \mathrm{~N} / 16 \mathrm{E}(2)$ & A.D. 570 & 5.0 & 0.0 & 5.0 & 0.0 & 105.0 & 115.0 & 70.0 & 0.0 & 135.0 & 440.0 & 672.6 \\
\hline $\mathrm{C}(3 \mathrm{C})$ & A.D. 420 & 0.0 & 0.0 & 0.0 & 0.0 & 25.5 & 25.5 & 25.5 & 6.4 & 165.6 & 222.9 & 827.3 \\
\hline $24.5 \mathrm{~S} / 77 \mathrm{E}(8)$ & A.D. 240 & 0.0 & 0.0 & 0.0 & 0.0 & 4.5 & 4.5 & 0.0 & 0.0 & 80.0 & 84.4 & 2342.0 \\
\hline $2 \mathrm{~N} / 35 \mathrm{E}(4)$ & A.D. 120 & 0.0 & 0.0 & 7.4 & 0.0 & 7.4 & 14.8 & 31.8 & 3.2 & 77.3 & 126.9 & 718.0 \\
\hline 2N/35E (5) & A.D. 5 & 0.0 & 19.4 & 0.0 & 0.0 & 70.9 & 90.3 & 64.5 & 25.8 & 290.3 & 470.7 & 1568.0 \\
\hline $2 \mathrm{~N} / 35 \mathrm{E}(6)$ and $\mathrm{A}(4 \mathrm{~A})^{b}$ & 2 B.C. & 0.0 & 10.0 & 13.3 & 0.0 & 53.3 & 76.7 & 16.7 & 6.7 & 280.0 & 380.0 & 1596.7 \\
\hline $\mathrm{B}(5 \mathrm{~A})$ & 320 B.C. & 0.0 & 0.0 & 0.0 & 0.0 & 0.0 & 0.0 & 0.0 & 0.0 & 36.0 & 36.0 & 842.1 \\
\hline $2 \mathrm{~N} / 35 \mathrm{E}(7)$ & 620 B.C. & 0.0 & 0.0 & 0.5 & 1.4 & 0.9 & 2.9 & 7.6 & 0.5 & 35.7 & 45.7 & 825.0 \\
\hline $\mathrm{A}(5 \mathrm{~A})$ & 770 B.C. & 0.0 & 0.0 & 0.0 & 0.0 & 2.1 & 2.1 & 0.0 & 27.1 & 291.7 & 320.8 & 193.4 \\
\hline $2 \mathrm{~N} / 35 \mathrm{E}(8)$ & 1270 B.C. & 2.4 & 2.4 & 0.0 & 0.0 & 16.9 & 21.7 & 21.7 & 2.4 & 19.3 & 65.1 & 1257.0 \\
\hline 2N/35E (9) & 1520 B.C. & 0.0 & 0.0 & 0.0 & 0.0 & 0.6 & 0.6 & 0.6 & 0.6 & 2.6 & 4.5 & 88.9 \\
\hline 2N/35E (10) & 1560 B.C. & 0.0 & 0.0 & 0.0 & 0.0 & 25.0 & 25.0 & 0.0 & 25.0 & 335.0 & 385.0 & 442.6 \\
\hline B (6) & $1740 \mathrm{~B} . \mathrm{C}$ & 0.0 & 67.5 & 35.0 & 2.5 & 272.5 & 377.5 & 35.0 & 103.0 & 515.0 & 1030.0 & 1666.0 \\
\hline $\mathrm{B}(6 \mathrm{~A})$ & 2250 B.C. & 0.0 & 35.3 & 0.0 & 0.0 & 94.1 & 129.4 & 0.0 & 106.0 & 211.8 & 447.1 & 2184.0 \\
\hline D-G Profile ${ }^{c}$ & 2480 B.C. & 4.3 & 0.0 & 1.4 & 0.0 & 27.2 & 32.9 & 37.1 & 38.6 & 800.0 & 908.6 & 1125.9 \\
\hline B (6B) & 2490 B.C. & 0.0 & 6.1 & 6.1 & 0.0 & 15.2 & 27.4 & 6.1 & 24.2 & 178.8 & 236.4 & 228.0 \\
\hline B (7B) & 2610 B.C. & 0.0 & 0.0 & 0.0 & 0.0 & 0.0 & 0.0 & 0.0 & 50.0 & 10.0 & 60.0 & 35.0 \\
\hline $28,29 \mathrm{~N} / 16 \mathrm{E}(4 \mathrm{~A})$ & 3640 B.C. & 0.0 & 0.0 & 0.0 & 0.0 & 0.0 & 0.0 & 0.0 & 10.0 & 90.0 & 100.0 & 1815.0 \\
\hline B (10) & 3650 B.C. & 0.8 & 0.0 & 0.0 & 0.0 & 0.0 & 0.8 & 0.0 & 0.0 & 0.0 & 0.8 & 6.2 \\
\hline $\begin{array}{l}28,29 \mathrm{~N} / 16 \mathrm{E}(4 \mathrm{~B}), 26 \\
\mathrm{~N} / 20,21 \mathrm{E}(8) \text { and } 31 \\
\mathrm{~N} / 11,12(8)^{6}\end{array}$ & 3770 B.C. & 0.0 & 0.0 & 3.3 & 0.0 & 13.3 & 16.7 & 0.0 & 96.7 & 325.0 & 440.0 & 703.5 \\
\hline $\mathrm{C}(6)$ & 3970 B.C. & 0.0 & 0.0 & 0.0 & 0.0 & 4.0 & 4.0 & 2.0 & 128.0 & 58.0 & 192.0 & 165.0 \\
\hline $\mathrm{A}(6)$ & 6160 B.C. & 0.0 & 0.0 & 0.0 & 0.0 & 0.0 & 0.0 & 0.0 & 5.8 & 28.9 & 34.8 & 5.7 \\
\hline 2N/35E (11) & 6380 B.C. & 1.6 & 0.0 & 1.6 & 0.0 & 9.7 & 12.9 & 0.0 & 3.2 & 30.7 & 46.8 & 93.5 \\
\hline $28,29 \mathrm{~N} / 16 \mathrm{E}(6)$ & 6440 B.C. & 0.0 & 0.0 & 0.0 & 0.0 & 90.0 & 90.0 & 5.0 & 15.0 & 790.0 & 900.0 & 109.9 \\
\hline C $(9 \mathrm{C})$ & 7040 B.C. & 0.0 & 0.0 & 0.0 & 0.0 & 28.6 & 28.6 & 0.0 & 0.0 & 0.0 & 28.6 & 0.0 \\
\hline
\end{tabular}

${ }^{a}$ Fish measured in $\mathrm{g} / \mathrm{m}^{3}$.

${ }^{b}$ Averaged values.

${ }^{c}$ Profile of house floor across four contiguous units; values are averaged. 
TABLE 5

Summary of Marine Mammal Bones from 1994 and 1996 Projects at Eel Point (CA-SCLI-43)

\begin{tabular}{|c|c|c|c|c|c|c|c|c|c|c|c|}
\hline \multirow{2}{*}{$\begin{array}{l}\text { Species, family } \\
\text { or class }\end{array}$} & \multicolumn{2}{|c|}{ Late period } & \multicolumn{2}{|c|}{$\begin{array}{l}\text { Undated } \\
\text { late/middle } \\
\text { period }\end{array}$} & \multicolumn{2}{|c|}{$\begin{array}{l}\text { Middle } \\
\text { period }\end{array}$} & \multicolumn{2}{|c|}{$\begin{array}{l}\text { Undated } \\
\text { middle/early }\end{array}$} & \multicolumn{2}{|c|}{ Early period } & \multirow{2}{*}{$\begin{array}{l}\text { Total } \\
\text { NISP }\end{array}$} \\
\hline & NISP & $\%$ & NISP & $\%$ & NISP & $\%$ & NISP & $\%$ & NISP & $\%$ & \\
\hline Pinnipedia & 355 & 9.2 & 90 & 8.8 & 284 & 6.2 & 32 & 7.7 & 30 & 13.0 & 791 \\
\hline Delphinidae & 51 & 1.3 & 289 & 28.3 & 557 & 12 & 19 & 4.6 & 6 & 2.6 & 922 \\
\hline Otters & 378 & 9.8 & 68 & 6.7 & 51 & 1.1 & 3 & $<1.0$ & 1 & $<1.0$ & 501 \\
\hline Large cetaceans & 32 & 1.0 & 98 & 9.6 & 55 & 1.2 & 4 & $<1.0$ & 0 & 0.0 & 189 \\
\hline Unidentified mammal & 3041 & 78.8 & 477 & 46.7 & 3646 & 79.4 & 359 & 86.0 & 192 & 83.8 & 7715 \\
\hline Total & 3857 & 100.0 & 1022 & 100.0 & 4593 & 100.0 & 417 & 100.0 & 229 & 100.0 & 10,118 \\
\hline
\end{tabular}

terrestrial breeders (Guadalupe fur seals and California sea lions) are not recorded until mid-Holocene when marine mammal remains became more abundant overall and sample size more significant (Table 7). Both species were heavily exploited preceding and following the early Holocene hiatus in site occupation (with a slight emphasis on Guadalupe fur seals), and both also declined after that time (Fig. 4). California sea lions subsequently re- bounded during the Holocene, with NISP values even greater than during the midHolocene. Remains of Guadalupe fur seals, however, show only a modest upturn prior to site abandonment ca. A.D. 1400. Guadalupe fur seals are the most sedentary of the pinnipeds that breed on the southern islands, with females occupying the breeding site on nearly a yearround basis (Robert DeLong, personal communication, 1998). It stands to reason

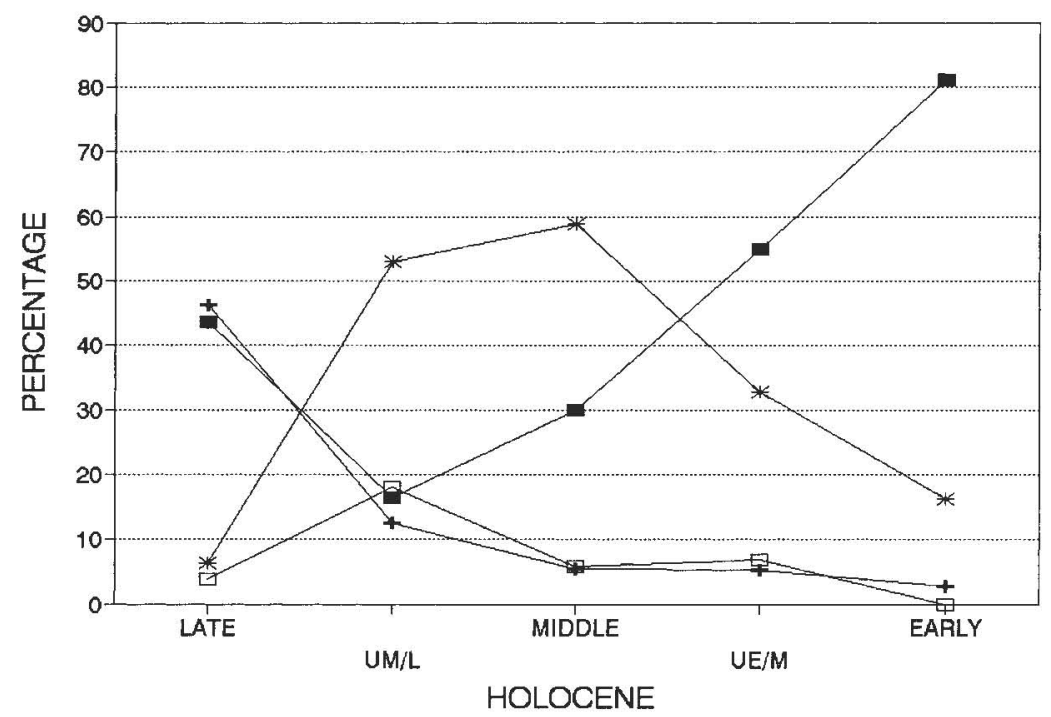

PINNIPEDS

SEA OTTERS

DELPHINIDAE ๑- LG. CETACEA

FIG. 3. Trans-Holocene patterns in faunal remains from the Eel Point Site, CA-SCLI-43. 

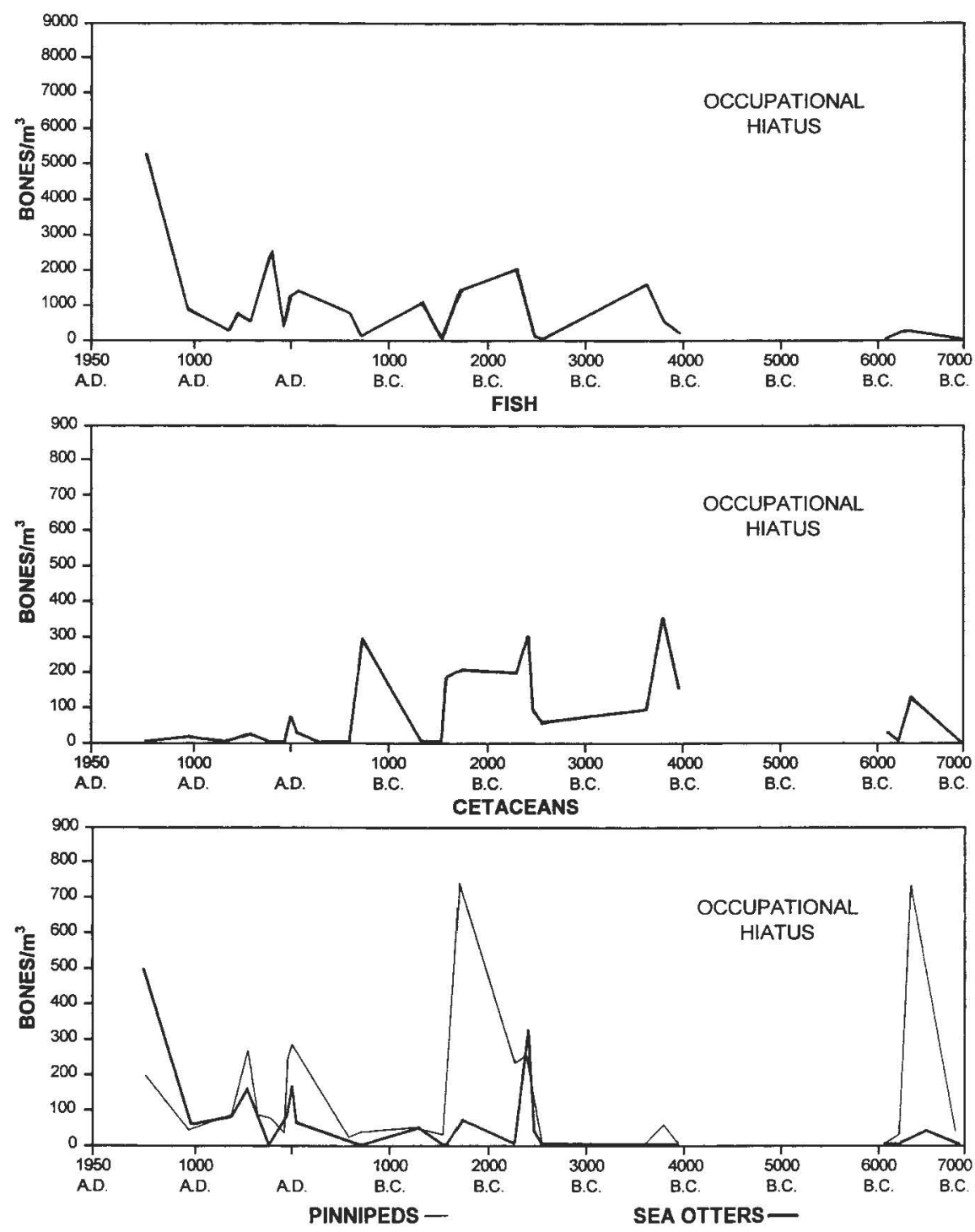

FIG. 4. Frequency $/ \mathrm{m}^{3}$ of fish (g), otter (NISP), pinniped (NISP), and cetacean (NISP) bone through time at Eel Point, CA-SCLI-43.

that this species was most susceptible to shore-based predation. Fur seals were impacted more heavily by historic sealing than were the less sedentary, warier California sea lions who managed to maintain a breeding presence on the Channel Islands throughout the period of historic decimation. Fur seals were relegated to near extinction, surviving only in a small colony on Guadalupe Island. The near disappearance of Guadalupe fur seals and the increase in otter bones through time are consistent with trends that Hildebrandt and Jones (1992) attributed to overexploitation of the more highly ranked terrestrial breeders and gradual increase in the exploitation of smaller, more elusive, non-terrestrial sea otters. While both 
TABLE 6

NISP/Temporal Period at CA-SCLI-43: Non-Terrestrial Breeders

\begin{tabular}{lrrrrrrrrr}
\hline & \multicolumn{2}{c}{ E. lutris } & & \multicolumn{2}{c}{ P. vitulina } & & & \\
\cline { 2 - 3 } Holocene period & Juvenile & Adult & & Juvenile & Adult & Delphinidae & Cetaceans & Total \\
\hline Early & 0 & 1 & & 0 & 1 & 6 & 0 & 8 \\
Early/Middle & 0 & 4 & & 0 & 0 & 20 & 4 & 28 \\
Middle & 16 & 39 & & 1 & 3 & 578 & 54 & 691 \\
Middle/Late & 28 & 66 & & 1 & 3 & 265 & 104 & 467 \\
Late & 132 & 215 & & 1 & 4 & 53 & 27 & 432 \\
Total & 176 & 325 & & 3 & 11 & 922 & 189 & 1626 \\
\hline
\end{tabular}

the Guadalupe fur seal and the California sea lion are consistently found in the Eel Point midden, these two species present entirely different patterns of utilization (Fig. 5). Although the few identified pinniped specimens in the early period are California sea lions, the quantity of remains of this animal during the remainder of the Holocene are highly variable and markedly cyclic. In contrast, the usage pattern of the fur seal is noncyclic and distinguished by an extreme "crash" following the middle Holocene peak.

The fine-grained Eel Point chronology also shows significant fluctuations in the intensity of marine mammal exploitation over time (Fig. 4). These fluctuations provide an additional explanation for the survival of sea lion breeding colonies on San Clemente Island despite the attractiveness and subsistence value of this re- source. Optimal foraging theory, in fact, suggests that resources should not be pursued to the point of extinction, as this would require increasingly suboptimal hunting (Smith 1983:632). While some measure of predatory pressure was in force throughout the Holocene, marine mammal populations apparently had time to recover periodically so that the longterm changes in dominant prey were accompanied by short-term fluctuations in population. This seems to have been accomplished by a short-term switching strategy in which alternative resources were pursued when the highest ranked foods became less available. Fish, in particular, show short-lived increases at times when other species decline (Fig. 4).

The overall increase in marine mammal bones at mid-Holocene is roughly synchronous with a similar increase in the

TABLE 7

NISP/Temporal Period at CA-SCLI-43: Terrestrial Breeders

\begin{tabular}{|c|c|c|c|c|c|c|c|c|c|}
\hline \multirow[b]{2}{*}{ Holocene period } & \multicolumn{2}{|c|}{ Z. californianus } & \multicolumn{2}{|c|}{ A. townsendi } & \multicolumn{2}{|c|}{ M. angustirostris } & \multicolumn{2}{|c|}{$\begin{array}{l}\text { Unidentified } \\
\text { pinniped }\end{array}$} & \multirow{2}{*}{$\begin{array}{l}\text { Total } \\
\text { NISP }\end{array}$} \\
\hline & Juvenile & Adult & Juvenile & Adult & Juvenile & Adult & Juvenile & Adult & \\
\hline Early & 0 & 1 & 0 & 0 & 0 & 0 & 7 & 19 & 27 \\
\hline Early/Middle & 0 & 0 & 0 & 2 & 0 & 1 & 11 & 20 & 34 \\
\hline Middle & 18 & 12 & 15 & 27 & 1 & 0 & 111 & 95 & 279 \\
\hline Middle/Late & 1 & 1 & 0 & 3 & 0 & 0 & 36 & 58 & 99 \\
\hline Late & 9 & 26 & 3 & 7 & 3 & 2 & 127 & 161 & 338 \\
\hline Total & 28 & 40 & 18 & 39 & 4 & 3 & 292 & 353 & 777 \\
\hline
\end{tabular}




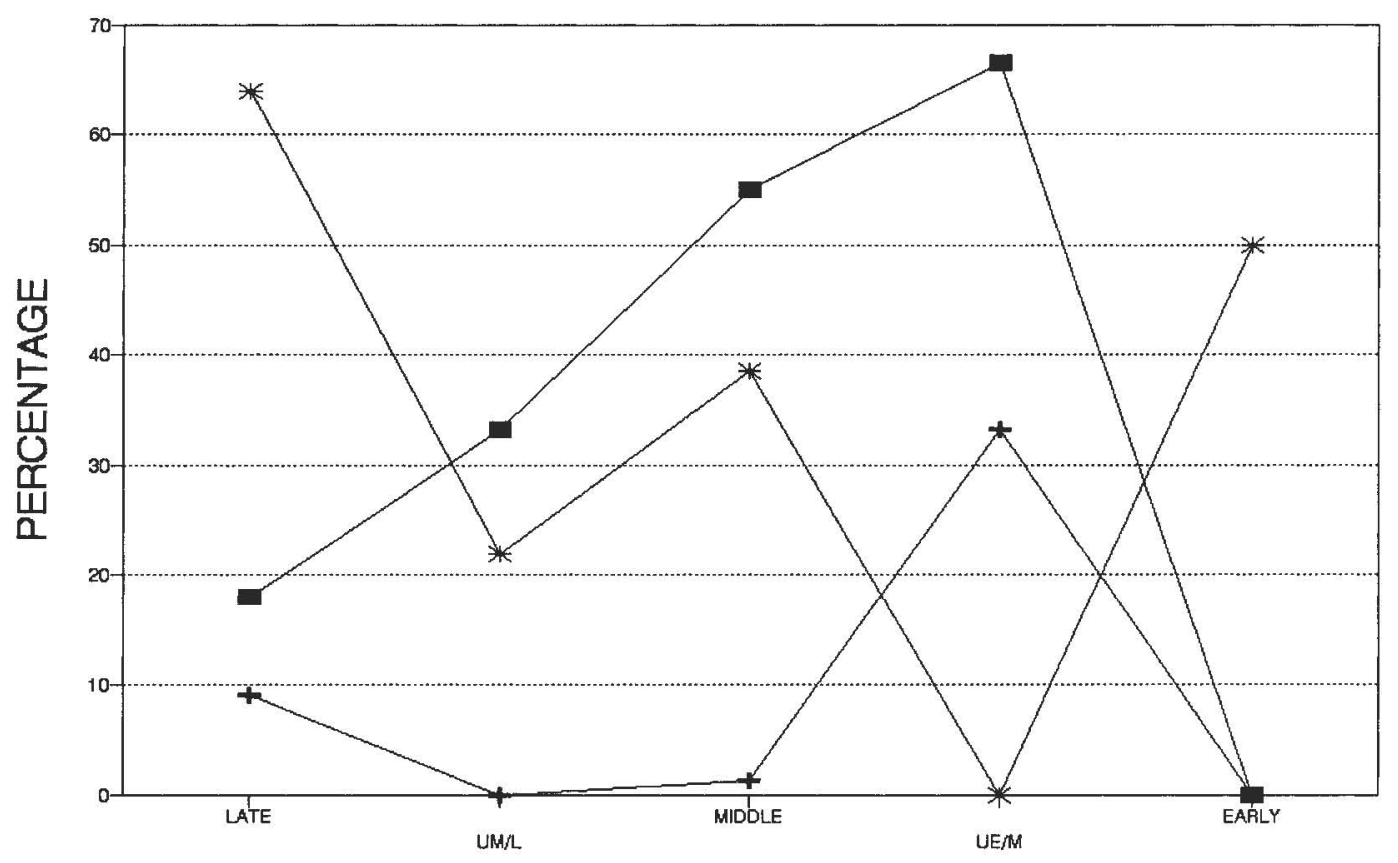

HOLOCENE

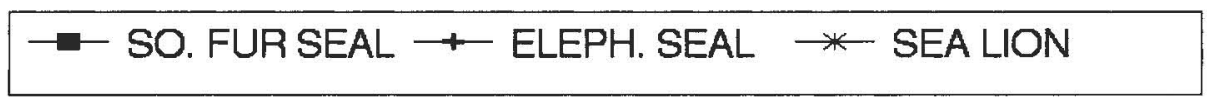

FIG. 5. Trans-Holocene patterns in large pinniped remains from Eel Point, CA-SCLI-43.

Santa Barbara Channel attributed by Glassow et al. (1988) and Glassow (1997) to a decline in sea temperatures and increased marine productivity. At Eel Point, however, this upturn follows a distinct hiatus in occupation. Whether related to paleoclimatic events (San Clemente Island is very poorly watered, and modest decreases in frequency/amount of rainfall could easily render all or parts of the island uninhabitable) or some other phenomenon, this hiatus may have given marine mammal populations a chance to recover from earlier exploitation, and renewed occupation brought with it heavy exploitation of rookeries. This scenario is similar to the one advanced by Jones and Hildebrandt (1995) to explain an apparent rebound in non-terrestrial breeder populations on the northern Channel Islands ca. A.D.1200 when so-called "Medieval droughts" (Graumlich 1993; Raab and Larson 1997; Stine 1994) disrupted settlement on the more poorly watered islands (Arnold 1992b). The Eel Point Site likewise appears to have been lightly occupied ca. A.D. $1020-1400$, which may also explain the increased frequency of California sea lion remains in the latest, preabandonment strata.

The other significant change in faunal density through time at Eel Point was in fish remains. Overall density of fish bone increases through time, with the highest numbers associated with the most recent site occupation (Fig. 4). As other classes of prey became increasingly scarce relative to the survival needs of the human population, the one resource susceptible to technological intensification was fish 
(Hildebrandt and Jones 1992). Whether or not they were hunted to near extinction, pinnipeds (especially the terrestrial breeders) have natural population ceilings (Estes 1979) that limit the potential for humans to exploit them intensively. Greater reliance on fishing is consistent with increased use of watercraft and, in concert with greater exploitation of sea otters, indicates that optimal foraging strategies gave way to less efficient ones during the course of the Holocene.

\section{Age/Sex Patterns}

Among the most profound findings from Eel Point is the fact that very few of the pinniped bones appear to represent adult males ( 26 elements or $5.6 \%$ of the adult pinniped bone collection). Based on size, the vast majority of adult bones represents females (440 elements or $94.4 \%$ of the adult pinniped collection). Of the entire pinniped collection, however, 329 elements (41.4\%) represent juveniles (Tables 6 and 7 ). Some of these bones were so poorly ossified (epiphyses lacking and ends of diaphyses unformed) that they probably represent fetal or neonatal animals. The high incidence of females, immature, and very young animals is consistent with exploitation of a rookery, while the low number of male elements suggests purposeful avoidance of large territorial bulls. It is not surprising that the inhabitants of Eel Point preferred females and their young, since it would have been extremely dangerous for hunters to approach the large, aggressive males while they were tending their harems. Furthermore, the enormous yield of meat and fat that would come from a large male kill would require sophisticated processing technology (e.g., oil extraction) to obtain full caloric value before spoiling. Females and their young represent much more convenient packages for killing, transport, and consumption. Their exploitation, however, while calorically optimal, is antithetical to resource conservation.

\section{Dolphin Exploitation}

While the patterns in pinniped and sea otter remains show reasonable correlations with an intensification/overexploitation model, trends in the frequency of dolphin bones at Eel Point are more intriguing and less consistent with previous models. Dolphin bones are not a significant component in most zooarchaeological assemblages along the California and Oregon coasts, and these animals were not considered in other recent discussions of prehistoric marine mammal hunting. Excavation results, however, indicate that dolphin bones occur in meaningful numbers in some southern Channel Island sites (Raab 1997; Raab et al. 1995), including Eel Point (Table 5, Fig. 4). Exploitation of cetacean carcasses washed up on shore, particularly larger species, is well-documented ethnographically along the California shoreline (e.g., Palou 1924: $62-63)$, but as live prey it is assumed that the delphinidae must have required watercraft and probably harpoons or strong nets. With respect to optimization and intensification, their temporal distribution should be similar to that of other lowranked, difficult-to-pursue taxa like sea otters. Yet the Eel Point assemblage shows heavy exploitation of dolphins at mid-Holocene with a precipitous decline thereafter (Table 5, Figs. 3 and 4). It is unlikely that this high frequency reflects shoreline scavenging. The remains of these animals dominate the assemblage by a considerable margin at this time depth. The abundance of small cetacean remains in all likelihood represents an increase in watercraft-based hunting much earlier than recent models suggest. The possibility of sophisticated maritime hunting at midHolocene on the southern California coast was raised decades ago by several authors 
(Harrison and Harrison 1966; Meighan 1959), but the notion was generally dismissed due to inadequate faunal, artifactual, and chronological data. The findings from Eel Point support if not validate these earlier suspicions, and further indicate that maritime intensification began early and possibly abruptly on San Clemente Island if not elsewhere in maritime southern California. Other signs of midHolocene intensification on San Clemente Island include large, well-defined residential features (house floors with associated pit/storage features) that imply a strong measure of sedentism (Raab 1997; Raab et al. 1994).

The temporal priority of small cetacean exploitation over sea otters, both of which required exploitation from watercraft, may reflect the greater food value of the large-bodied, blubbery delphinidae. Otters have very little fat and represent much lower potential food value. Increased otter exploitation may also have been more related to the value of otter pelts as trade commodities. With this supplemental value, otters were worth pursuing when other resources became less available during the late Holocene.

\section{DISCUSSION}

Several variables that remain uncontrolled for the Eel Point collection may have contributed to patterns over time in the faunal assemblages. Seasonality of site occupation, for example, may have influenced the proportion of some taxa (sea lions and elephant seals) in different strata. Sea level rise has probably also affected the composition of assemblages, as Eel Point was located further inland at the time of its initial occupation than it is now. As a consequence, the so-called "schlep effect" may have operated differently when the site was closer to the shoreline. Nonetheless, the Eel Point data accommodate a model of overexploitation, albeit one that also incorporates other ecological factors, including paleoenvironmental flux and its impact on settlement and human population history. Broad patterns over time generally support the Jones and Hildebrandt (1995) and Broughton (1994) contention that smaller, less profitable species (sea otters) superseded more highly ranked terrestrially breeding species (fur seals, sea lions, elephant seals, and deer) through the course of the Holocene along the shores of the northeastern Pacific. On San Clemente Island, however, dense accumulations of cetacean bones in mid-Holocene strata indicate that the process of maritime intensification and skilled use of watercraft in sea-based hunting began much earlier than has been previously suspected. Pinniped exploitation gave way initially to watercraft-based pursuit of small cetaceans and later to heavy exploitation of sea otters and fish. Marked reduction in the remains of fur seals, in particular, suggests they were less available in the late Holocene than during previous periods. Pinnipeds were being exploited ca. 7040 B.C. at Eel Point, which represents the earliest evidence for their pursuit by humans yet reported from the coast of California and Oregon. While Hildebrandt and Jones (1992) suggested these resources were highly attractive to the initial colonists of western North America, Eel Point provides the first empirical evidence of such exploitation.

Concepts of optimization and intensification provide effective explanation for patterns in the marine mammal assemblages from Eel Point when paleoclimatic contextual variables are also considered. Paleoclimatic factors (especially drought) seem to have influenced the history of human occupation and at times influenced the intensity of predatory pressure on marine mammal populations. A marked increase in pinniped exploitation at mid-Holocene seems consistent with patterns in the northern Channel Islands 
noted by Glassow et al. (1988) and Glassow (1997), who attribute the increase to enhanced marine vitality related to a decline in sea temperatures. On San Clemente Island, strata with high pinniped bone frequency seem to correlate with a period of generally warm seas as identified in both early (Pisias 1978, 1979) and more recent paleo sea temperature reconstructions (Kennett 1998:123). Furthermore, the mid-Holocene increase on San Clemente follows a hiatus in occupation during which pinniped populations apparently rebounded in the absence of humans. Paleoclimatic conditions (e.g., warm, dry mid-Holocene climate) may have been the cause underlying the hiatus, but a direct causal relationship between change in marine mammal exploitation and climate is not indicated. Nonetheless, it remains important to consider historical/environmental variables in development of local models of marine mammal/human population ecology.

As the pursuit of highly ranked marine mammals began early and continued intermittently through the Holocene, gradual reduction in the population was almost inevitable, particularly in light of an apparent focus on females and juveniles. This sex/age emphasis was probably optimal with respect to calories, transport, and processing costs, and also avoided the dangers associated with hunting large bulls. Any human population exploiting pinnipeds with relatively crude technology would have, of necessity, focused on large groups of females and young. Self interest and conservation were mutually exclusive objectives in this instance, and there seems little justification for denying the inevitability of nonconservative behavior under such circumstances. Even if the inhabitants of San Clemente Island attempted a measure of management-oriented selectivity in their exploitation of migratory herds, it would have been to no avail. Previous studies (Hildebrandt and
Jones 1992) show that these animals were pursued at every location where they hauled out on land. The same animals that gave birth on San Clemente Island and avoided pursuit there were subsequently hunted by other Native peoples on other islands or the mainland. Effective management of these populations would have required hundreds of Native communities up and down the west coast of North America to adhere to mutual conservation-oriented hunting policies. This seems extremely unlikely in light of high human population densities during the late Holocene in California and Oregon.

\section{ACKNOWLEDGMENTS}

This paper was made possible through generous access to comparative collections and assistance offered by the directors of the Zooarchaeology Laboratory, UCLA Cotsen Institute of Archaeology (Jean Hudson and Tom Wake), Paul Collins, Curator of Vertebrate Zoology, Santa Barbara Museum of Natural History; and Dave Janiger, Curatorial Assistant, Natural History Museum of Los Angeles County. Special thanks are given to Mark Raab of California State University, Northridge, and Andrew Yatsko of the Navy's Natural Resources Office, Naval Air Station, North Island, San Diego, for giving us the opportunity to participate in the Eel Point project. We are also indebted to Christine Fiore for the Eel Point site map (based on original work by Andrew Yatsko) and to Rusty van Rossman for compiling Figs. 1 and 4 .

\section{REFERENCES CITED}

Arnold, J. E.

1992a Complex hunter-gatherer-fishers of prehis toric California: Chiefs, specialists, and mar itime adaptations of the Channel Islands. American Antiquity 57:60-84.

1992b Cultural disruption and the political economy in Channel Islands prehistory. In Essays on the prehistory of maritime California, edited by T. L. Jones, pp. 129-144. Center for Archaeological Research at Davis, Publication No. 10, University of California, Davis.

1995 Transportation innovation and social complexity among maritime hunter-gatherer societies. American Anthopologist 97:733-747. 
1997 Bigger boats, crowded creekbanks: Environmental stresses in perspective. American Antiquity 62:337-339.

Arnold, J. E., R. H. Colten, and S. Pletka

1997 Contexts of cultural change in insular California. American Antiquity 62:300-318.

Armstrong, D. V.

1985 Archaeology on San Clemente Island, summer 1985. Manuscript on file, Natural Resources Office, Naval Air Station, North Island, San Diego.

Axford, L. M.

1978 Current archaeological investigations on San Clemente Island, California. Manuscript on file, Natural Resources Office, Naval Air Station, North Island, San Diego.

1984 Four Years of Archaeological Investigations on San Clemente Island, California. Manuscript on file, Natural Resources Office, Naval Air Station, North Island, San Diego.

Aycock, R. D.

1983 An early Channel Island site: Excavations at Eel Point, San Clemente Island, California. Manuscript on file, Department of Anthropology, University of California, Los Angeles.

Bartholomew, G. A., Jr.

1967 Seal and sea lion populations of the California islands. In Proceedings of symposium on the biology of the California islands, edited by R. N. Philbrick, pp. 229-244. Santa Barbara Botanic Garden, Santa Barbara.

Basgall, M. E.

1987 Resource intensification among huntergatherers: Acorn economies in prehistoric California. Research in Economic Anthropology 9:21-52.

Bean, L. J., and H. Lawton.

1976 Some explanations for the rise of cultural complexity in native California with comments on proto-agriculture and agriculture. In Native Californians: A theoretical retrospective, edited by L. J. Bean and T. C. Blackburn, pp. 19-48. Ballena Press, Menlo Park, CA.

Beaton, J. M.

1991 Extensification and intensification in central California prehistory. Antiquity 65:946-952.

Blackburn, T. C., and K. Anderson

1993 Before the wilderness: Environmental management by Native Californians. Ballena Press, Menlo Park, CA.

Botkin, S.

1980 Effects of human exploitation on shellfish populations at Malibu Creek. In Modeling change in prehistoric subsistence economies, ed- ited by T. K. Earle and A. L. Christenson, pp. 121-139. Academic Press, New York.

Broughton, J. M.

1994 Declines in mammalian foraging efficiency during the late Holocene, San Francisco Bay, California. Journal of Anthropological Archaeology 13:371-401.

Colten, R. H.

1993 Prehistoric subsistence, specialization, and economy in a southern California chiefdom. Ph.D dissertation, Department of Archaeology, University of California, Los Angeles.

1995 Faunal exploitation during the Middle to Late Period transition on Santa Cruz Island, California. Journal of California and Great Ba sin Anthropology 17:93-120.

Davenport, D., J. R. Johnson, and J. Timbrook

1993 The Chumash and the swordfish. Antiquity $67: 257-272$.

Edgerton, R. B.

1992 Sick societies: Challenging the myth of primitive harmony, The Free Press, New York.

Estes, J. A.

1979 Exploitation of marine mammals: R-selection of $\mathrm{k}$ strategists? Journal of the Fisheries Research Board of Canada 36:1009-1017.

Geist, V.

1996 Buffalo nation: History and legend of the North American bison. Voyageur Press, Stillwater, Minnesota.

Gifford, E. W.

1916 Composition of California shellmounds. University of California Publications in American Archaeology and Ethnology 11:291-296.

Glassow, M. A.

1997 Middle Holocene cultural development in the central Santa Barbara Channel region. In Archaeology of the California coast during the middle Holocene, edited by J. M. Erlandson and M. A. Glassow, pp. 73-90. Institute of Archaeology, University of California, Los Angeles.

Glassow, M. A., L. Wilcoxon, and J. M. Erlandson

1988 Cultural and environmental change during the Early Period of Santa Barbara Channel prehistory. In The archaeology of prehistoric coastlines, edited by G. Bailey and J. Parkington, pp. 64-77. Cambridge University Press, New York

Graumlich, L. J,

1993 A 1000-year record of temperature and precipitation in the Sierra Nevada. Quaternary Research 39:249-255. 
Harrison, W. M., and E. S. Harrison

1966 An archaeological sequence for the hunting people of Santa Barbara, California. University of California Los Angeles Archaeological Survey Annual Report 1965-1966:1-89.

Hawkes, K., K. Hill, and J. F. O'Connell

1982 Why hunters gather: Optimal foraging and the Ache of eastern Paraguay. American Ethnologist 9:379-398.

Hildebrandt, W. R., and T. L. Jones

1992 Evolution of marine mammal hunting: A view from the California and Oregon coasts. Journal of Anthropological Archaeology 11:360 401.

Hunn, E. S., and N. M. Williams

1982 Introduction. In Resource managers: North American and Australian hunter-gatherers, edited by N. M. Williams and E. S. Hunn, pp. 1-16. Westview Press, Boulder, Colorado.

Ingles, L.G.

1947 Mammals of the Pacific states, California, Oregon, and Washington. Stanford Univ. Press, Stanford.

Jameson, E. W., Jr., and H. J. Peeters

1988 California mammals. University of California Press, Berkeley.

Jones, T. L., and W. R. Hildebrandt

1995 Reasserting a prehistoric tragedy of the commons: Reply to Lyman. Journal of Anthropological Archaeology 14:78-98.

Kay, C.

1990 Yellowstone's northern elk herd: A critical evaluation of the "natural regulation paradigm." Ph.D. dissertation, Department of Biology, Utah State University, Logan.

1994 Aboriginal overkill: The role of Native Americans in structuring western ecosystems. Human Nature 5:359-398.

Keeley, L. H.

1996 War before civilization. Oxford Univ. Press, New York.

Kennett, D. J.

1998 Behavioral ecology and the evolution of huntergatherer societies on the northern Channel Islands, California. Ph.D. dissertation, Department of Anthropology, University of California, Santa Barbara.

Lambert, P. M.

1993 Health in prehistoric populations of the Santa Barbara Channel Islands. American Antiquity 58:509-522.

Lambert, P. M., and P. L. Walker

1991 Physical anthropological evidence for the evolution of social complexity in coastal southern California. Antiquity 65:963-973.
Lyman, R. L.

1991 Prehistory of the Oregon coast. Academic Press, New York.

1995 On the evolution of marine mammal hunting on the west coast of North America. Journal of Anthropological Archaeology 14:4577 .

Martin, P. S.

1967 Prehistoric overkill. In Pleistocene extinctions: The search for a cause, edited by P. S. Martin and H. E. Wright, pp. 75-120. Yale Univ. Press, New Haven, CT.

McKusick, M. B., and C. N. Warren

1959 Introduction to San Clemente Island Ar chaeology. Annual Report of the University of California Archaeological Survey 1958-1959: $107-186$.

Meighan, C. W.

1959 The Little Harbor Site, Catalina Island: An example of ecological interpretation in archaeology. American Antiquity 24:383-405.

1984 Archaeology on San Clemente Island, summer 1984. Manuscript on file, Natural Resources Office, Naval Air Station, North Island, San Diego.

1986 UCLA archaeological research on San Clemente Island, 1986. Manuscript on file, Natural Re sources Office, Naval Air Station, North Is land, San Diego.

Moratto, M. J.

1984 California archaeology. Academic Press, Orlando, FL.

O'Connell, J. F., and K. Hawkes

1981 Alywara plant use and optimal foraging theory. In Hunter-gatherer foraging strategies, edited by B. Winterhalder and E. A. Smith, pp. 99-125. Univ. of Chicago Press, Chicago.

Odell, D. K.

1981 California sea lion, Zalophus californianus (Lesson, 1828). In Handbook of marine mammals, volume 1: The walrus, sea lions, fur seals and sea otter, edited by S. H. Ridgway and R. J. Harrison, pp. 67-97. Academic Press, London.

Ono, K. A.

1991 Introductory remarks and the natural history of the California sea lion. In Pinnipeds and the EI Niño, edited by F. Trillmich and K. A. Ono, pp. 109-111. Springer-Verlag, Berlin.

Palou, F.

1924 Description of the Indians in the vicinity of Mission San Francisco, 1776. In San Francisco or Mission Dolores, edited by Z. Engelhardt, 
pp. 59-64. Franciscan Herald Press, Chicago.

Pisias, N. G.

1978 Paleoceanography of the Santa Barbara Basin during the last 8,000 years. Quaternary Research 10:366-384.

1979 Model for paleoceanographic reconstruction of the California current for the last 8,000 years. Quaternary Research 11:373-386.

Porcasi, J. F.

1995 Trans-Holocene marine mammal hunting on San Clemente Island, California: Additional data to assess a prehistoric "tragedy of the commons" and declining mammalian foraging efficiency. Unpublished M.A. thesis, Department of Anthropology, California State University, Northridge.

Raab, L. M.

1997 The southern Channel Islands during the middle Holocene: Trends in maritime cultural evolution. In Archaeology of the California coast during the middle Holocene, edited by J. M. Erlandson and M. A. Glassow, pp. 2334. Institute of Archaeology, University of California, Los Angeles.

Raab, L. M., K. Bradford, J. F. Porcasi, and W. J. Howard

1995 Return to Little Harbor, Santa Catalina Island, California: A critique of the marine paleotemperature model. American Antiquity 60:287-308.

Raab, L. M., K. Bradford, and A. Yatsko

1994 Advances in southern Channel Island archaeology: 1983-1993. Journal of California and Great Basin Anthropology 16:243-270.

Raab, L. M., and D. O. Larson

1997 Medieval climatic anomaly and punctuated cultural evolution in coastal Southern California. American Antiquity 62:319-336.

Raab, L. M., and A. Yatsko

1992 Ancient maritime adaptations of the California Bight: A perspective from San Clemente Island. In Essays on the prehistory of maritime California, edited by T. L. Jones, pp. 173-193. Center for Archaeological Research at Davis, Publication No. 10, University of California, Davis.

Salls, R. A.

1988 Prehistoric fisheries of the California bight. Unpublished Ph.D. dissertation, Department of Archaeology, University of California, Los Angeles.

1989 Marine adaptation of the California islands as viewed from a prehistoric "tackle box." In A step into the past: Island dwellers of southern
California, edited by J. Smull and T. Cox, p. 16. Museum of Anthropology, California State University, Fullerton.

1990 The ancient mariners: Ten thousand years of marine exploitation at Eel Point, San Clemente Island, California. Pacific Coast Archaeological Society Quarterly 26:61-92.

1991 Early Holocene maritime adaptation at Eel Point, San Clemente Island. In Hunter-gatherers of early Holocene coastal California, edited by J. M. Erlandson and R. H. Colten, pp. 63-80. Institute of Archaeology, University of California, Los Angeles.

1992 Prehistoric subsistence change on California's Channel Islands: Environmental or cultural? In Essays on the Prehistory of Maritime California, edited by $\mathrm{T}$. L. Jones, $\mathrm{pp}$. 157-172. Center for Archaeological Research at Davis, Publication No. 10, University of California, Davis.

Scammon, C. M.

1874 The marine mammals of the northwestern coast of North America. John Carmany and Sons, San Francisco.

Smith, E. A.

1983 Anthropological applications of optimal for aging theory. Current Anthropology 24:625651.

Stine, S.

1994 Extreme and persistent drought in Califor nia and Patagonia during mediaeval time. Nature 369:546-548.

Stuiver, M., and P. J. Reimer

1993 Extended 14C data base and revised CALIB $3.014 \mathrm{C}$ age calibration program. Radiocarbon $35: 215-230$.

Stuiver, M., and T. F. Braziunas

1993 Modeling atmospheric ${ }^{14} \mathrm{C}$ influences and ${ }^{14} \mathrm{C}$ ages of marine samples to 10,000 B.C. Radiocarbon 35:137-189.

Taylor, R. E.

1987 Radiocarbon dating, An archaeological perspective. Academic Press, New York.

Trillmich, F.

1991 Introductory remarks on the natural history of fur seals. In Pinnipeds and EI Niño, edited by F. Trillmich and K. A. Ono, pp. 45-46. Springer-Verlag, Berlin.

Truett, J.

1996 Bison and elk in the American Southwest: In search of the pristine. Environmental Management 20:195-206.

Williams, N. M., and E. Hunn

1982 Resource managers: North American and Australian hunter-gatherers. Westview Press, Boulder, CO. 